\title{
PERBEDAAN IMT, HEMOGLOBIN, ALBUMIN, UREUM DAN KREATININ PADA PASIEN HEMODIALISA DENGAN DAN TANPA DIABETES MELITUS DI RSIJ CEMPAKA PUTIH (DATA SEKUNDER)
}

\author{
Differences Of BMI, Hemoglobin, Albumin, Ureum And Creatinine In Hemodialized \\ Patients With And Without Diabetes Mellitus In RSIJ Cempaka Putih (Secondary \\ Data)
}

\author{
Ainun Nurhaliza', Mertien Sa'pang ${ }^{2}$, Yulia Wahyuni ${ }^{1}$, Anugrah Novianti ${ }^{1}$ \\ ${ }^{1}$ Program Ilmu Gizi, Fakultas Ilmu-Ilmu Kesehatan, Universitas Esa Unggul, \\ ${ }^{2}$ Program Studi Profesi Dietisian, Fakultas Ilmu-Ilmu Kesehatan, Universitas Esa \\ Unggul, \\ mertien.sapang@esaunggul.ac.id
}

\begin{abstract}
Malnutrition in hemodialysis patients is one of the factors that can increase patient morbidity and mortality. For this reason, it is necessary to assess nutritional status on a regular basis, assessment of nutritional status that can be done in hemodialysis patients is to use anthropometry, namely BMI calculations, and biochemistry. The presence of comorbidities, such as diabetes mellitus (DM), is one of the risks of malnutrition. The aim is to analyze differences in body mass index (BMI), hemoglobin, albumin, urea and creatinine levels in hemodialysis patients with and without diabetes mellitus at RSIJ Cempaka Putih (Secondary Data). The research design is cross sectional. Sampling using the Proportionate Stratified Random Sampling technique with a total sample of 66 respondents. BMI data used dry weight and height of the patient, as well as levels of $\mathrm{Hb}$, albumin, urea, and creatinine obtained from the medical records of the respondents. Bivariate data analysis using Independent T-test and Mann-Whitney test. The results showed that there were differences between BMI (pValue=0.0001), Hb (pValue=0.0001), albumin (pValue=0.0001), urea ( $p$ Value $=0.0001)$, and creatinine $(p$ Value $=0.0281)$ in hemodialysis patients with and without diabetes mellitus.. In conclusion, there are differences between BMI, Hb, albumin, urea, and creatinine in hemodialysis patients with and without diabetes mellitus.
\end{abstract}

Keywords: Hemodialysis, Diabetes Mellitus, Malnutrition, Anemia

\begin{abstract}
ABSTRAK
Malnutrisi pada pasien hemodialisis menjadi salah satu faktor yang dapat meningkatkan morbiditas dan mortalitas pasien. Untuk itu perlu dilakukan penilaian status gizi secara rutin, penilaian status gizi yang dapat dilakukan pada pasien hemodialisis adalah dengan menggunakan antropometri yaitu perhitungan IMT, dan biokimia. Adanya penyakit penyerta seperti diabetes mellitus, menjadi salah satu resiko terjadinya malnutrisi. Tujuan dari penelitian ini yaitu menganalisis Perbedaan Indeks Massa Tubuh (IMT), Kadar Hemoglobin, Albumin, Ureum Dan Kreatinin Pada Pasien Hemodialisa Dengan Dan Tanpa Diabetes Melitus Di RSIJ Cempaka Putih (Data Sekunder). Desain penelitian ini adalah cross sectional. Pengambilan sampel menggunakan teknik Proportionate Stratified Random Sampling dengan total sampel sebanyak 66 responden. Data IMT menggunakan BB kering dan TB pasien, serta kadar Hb, albumin, ureum, dan kreatinin yang diperoleh dari rekam medik responden. Analisa data bivariat menggunakan uji T-test Independen dan Mann-Whitney. Hasil penelitian menunjukkan ada perbedaan antara IMT ( $\mathrm{pValue}=0,0001$ ), kadar hemoglobin (pValue=0,0001), albumin (pValue=0,0001), ureum (pValue=0,0001), dan kreatinin $(\mathrm{pValue}=0,0281)$ pada pasien hemodialisis dengan dan tanpa diabetes mellitus. Kesimpulannya, ada perbedaan antara IMT, kadar hemoglobin, albumin, ureum, dan kreatinin pada pasien hemodialisis dengan dan tanpa diabetes mellitus.
\end{abstract}

Kata Kunci: Hemodialisis, Diabetes Melitus, Malnutrisi, Anemia 


\section{PENDAHULUAN}

Gagal ginjal kronik (GGK) diklasifikasikan menjadi 5 stadium sesuai dengan penurunan LFG (Laju Filtrasi Gomerulus). Stadium 5 merupakan stadium akhir dari gagal ginjal kronik atau disebut juga end-stage renal disease (ESRD). Pada penderita yang sudah mencapai stadium 4 (nilai LFG $<30 \mathrm{~mL} / \mathrm{menit} / 1,73 \mathrm{~m} 2$ ) juga harus memulai terapi hemodialisis (Aisara, et al., 2018). Tindakan hemodialisis (HD) berfungsi untuk mengeluarkan zat-zat sisa metabolisme atau toksik seperti ureum, kreatinin, dan asam urat, serta kelebihan cairan dari dalam tubuh yang tidak dapat dikeluarkan oleh ginjal akibat adanya kerusakan ginjal. Indonesia Renal Registry tahun 2018 melaporkan bahwa pasien aktif GGK yang menjalani HD meningkat sebesar 54.250 pasien dari tahun 2017, dengan total pasien aktif sebanyak 132.142 pasien. Dengan faktor penyebab atau comorbid tertinggi kedua adalah diabetes mellitus (DM) yaitu sebesar 28\% (Indonesia Renal Registry, 2018).

Proses hemodialisis menyebabkan pengeluaran sisa metabolisme lebih cepat, seperti asam amino dalam bentuk albumin dan gula darah (glukosa), hal ini dapat mengakibatkan hipoalbuminemia dan menurunnya kadar gula dalam darah pasien yang dapat menyebabkan hipoglikemia. Pada pasien GGK dengan DM menurunnya kadar gula darah $20 \%$ terjadi lebih besar dibandingkan dengan GGK tanpa DM.
Kondisi tersebut dapat menyebabkan dialysisassosiated symptoms seperi sakit kepala, mual, dan muntah paska HD (Hartini, et al., 2014). Kondisi mual dan muntah menyebabkan resiko malnutrisi yang tinggi pada pasien yang menjalani HD, pravelensi malnutrisi diperkirakan sebesar $18-75 \%$ pada pasien HD (Angraini, 2015).

Penanda malnutrisi seperti Indeks Massa Tubuh (IMT) mempengaruhi domain fisik kualitas hidup pasien GGK yang menjalani HD (Spiegel et al., 2008; Astrini, 2013). Komplikasi lain yang sering terjadi pada pasien GGK adalah anemia, ditandai dengan konsentrasi hemoglobin $(\mathrm{Hb})$ yaitu < $13 \mathrm{gr} / \mathrm{dl}$ pada laki-laki dewasa dan $<12 \mathrm{gr} / \mathrm{dl}$ pada wanita dewasa (WHO, 2014). Faktor yang menyebabkan terjadinya anemia pada pasien GGK yang menjalani HD adalah defisiensi hormon eritropoetin (EPO) dan defisiensi besi. Selain itu, penggunaan obatobatan pada penderita diabetes mellitus juga memiliki kontraindikasi sehingga menyebabkan penurunan produksi sel darah merah (Anita, 2015).

Hipoalbuminemia terjadi akibat kehilangan protein dalam bentuk albumin selama proses HD atau urin (mikroalbuminuria) sehingga albumin serum darah < 3,5 g/dl. Albumin merupakan penanda biokimia yang umum digunakan untuk mengetahui keadaan status gizi pada penderita gagal ginjal kronik. Adanya 
komplikasi mikrovaskular pada penderita diabetes mellitus juga dapat menyebabkan albuminuria (keluarnya albumin melalui urin). Selain itu, rendahnya nilai albumin pada pasien HD selain dipengaruhi oleh asupan protein harian, juga dipengaruhi oleh penyakit penyerta salah satunya adalah DM (Latifah, et al., 2012).

Tingginya kadar ureum dan kreatinin di dalam darah dapat bersifat racun bagi tubuh dan dapat mempengaruhi status gizi pasien akibat toksik uremik (Chadijah and Wirawanni, 2013). Kenaikan kadar ureum dalam darah akan akan selalu dibarengi dengan kenaikan kadar kreatinin dalam darah. kreatinin serum pria lebih tinggi daripada wanita, yang disebabkan adanya perbedaan massa otot yang lebih besar pada pria dibandingkan dengan wanita (Verdiansah, 2016). Pemeriksaan kadar biokimia ureum dan kreatinin dalam darah sebelum dan sesudah HD berfungsi untuk memonitoring keberhasilan terapi HD dalam menggantikan fungsi ginjal dalam mengeluarkan zat-zat sisa metabolisme tersebut. Adanya gangguan gastrointestinal mual, muntah, dan anoreksia yang sering terjadi pada pasien hemodialisis

\section{METODE}

\section{Desain, Tempat, dan Waktu}

\section{Penelitian}

Penelitian ini menggunakan desain penelitian ini cross sectional. Dilakukan pada pasien HD dengan dan tanpa DM di RSIJ juga menjadi faktor resiko malgizi pada pasien gagal ginjal kronik hemodialisis. Prosedur HD pada pasien GGK menyebabkan kehilangan zat gizi, sehingga sebagai kompensasinya, asupan makanan, berat badan, serta nilai biokimia seperti BUN (Blood Urea Nitrogen), kreatinin, hemoglobin dan albumin harus dimonitor (Damayanti, 2017).

Berdasarkan data dan uraian diatas, pasien GGK dengan DM dan tanpa DM yang menjalani HD sangat beresiko mengalami malgizi dan anemia yang dapat meningkatkan morbiditas dan mortalitas pasien. Berdasarkan survey data awal yang dilakukan oleh peneliti, data pasien gagal ginjal kronik yang menjalani hemodialisis di RS Islam Jakarta Cempaka Putih pada tahun 2020 berjumlah 185 orang, dengan faktor penyebab dan penyakit penyerta tertinggi kedua pada pasien HD adalah DM yaitu sebesar 40\%. Dari latar belakang ini maka peneliti tertarik untuk mengetahui perbedaan Indeks Massa Tubuh (IMT), kadar hemoglobin, albumin, ureum dan kreatinin pada pasien hemodialisa dengan dan tanpa diabetes melitus di RS Islam Jakarta Cempaka Putih.

Cempaka Putih, Jakarta Pusat. Dilaksanakan pada bulan Juni - Juli 2021, yang meliputi pengambilan data, analisis data, dan penyusunan laporan. Data penelitian ini bersumber dari data sekunder yang 
J.Gipas, November 2021, Volume 5 Nomor 2

ISSN 2599-0152 eISSN 2599-2465

http://jos.unsoed.ac.id/index.php/jgps

didapatkan dari rekam medik pasien. Penelitian ini telah lulus izin etik penelitian Universitas Esa Unggul dengan nomor 011321.113

/DPKE-KEP/FINAL-

EA/UEU/IV/2021.

Jumlah Dan Cara Pengambilan Subjek Penelitian

Pengambilan sampel menggunakan teknik Proportionate Stratified Random Sampling dengan total sampel sebanyak 66 responden yang terdiri dari 30 responden kelompok GGK dengan DM dan 36 responden kelompok GGK tanpa DM. Kriteria inklusi pada penelitian ini adalah pasien hemodialisis RSIJ Cempaka Putih dengan akses HD cimino atau Arteri-Venous Fistula dan lama HD $\geq 1$ tahun, menjalani HD rutin (minimal 2 kali dalam seminggu), memiliki data rekam medik nilai laboratorium yaitu kadar hemoglobin, albumin, ureum, dan kreatinin. Sedangkan untuk kriteria ekslusi pada penelitian ini adalah pasien dalam keadaan kronis seperti koma atau penyakit kronis lain.

Jenis dan Cara Pengumpulan Data/LangkahLangkah Penelitian

Pengukuran IMT didapatkan dengan membagi berat badan kering dalam $\mathrm{kg}$ dan tinggi badan responden dalam $\mathrm{m}^{2}$. Niali antropometri dan biokimia responden didapatkan dari data rekam medik, dengan jarak data yang digunakan dari pengambilan data antropometri atau biokimia maksimal 3 bulan.

\section{Analisis Data}

Data yang sudah terkumpul kemudian diolah menggunakan program komputer SPSS version 25 for Windows dan dianalisis secara univariat dan bivariat menggunakan Uji $T$ Test Independent yaitu IMT, kadar $\mathrm{Hb}$, dan kreatinin dan Uji Mann-whitney yaitu kadar albumin dan ureum.

\section{HASIL DAN PEMBAHASAN}

Dalam penelitian ini, pasien hemodialisa dengan dan tanpa diabetes mellitus memiliki perbedaan fisiologis diantara kedua kelompok akibat penyakit penyertanya yaitu diabetes mellitus, sehingga menyebabkan kondisi pada pasien hemodialisa dengan diabetes mellitus berbeda dengan pasien hemodialisa tanpa diabetes mellitus, dimana pada penelitian ini sebagian besar pasien hemodialisa tanpa diabetes mellitus memiliki penyakit penyerta hipertensi. Adanya perbedaan fisiologi yang mendasar pada pasien hemodialisa dengan diabetes mellitus menyebabkan kondisi yang lebih beresiko terkait dengan kondisi kesehatan pasien yang dapat dilihat dari nilai antropometri dan juga nilai biokimia. Oleh karena itu, dalam penelitian ini dilakukan penelitian terkait perbedaan indeks massa tubuh dan nilai biokimia yaitu hemoglobin, albumin, ureum, dan kreatinin pada pasien hemodialisa dengan dan tanpa diabetes mellitus di RS Islam Jakarta Cempaka Putih dengan melihat rekam medis pasien. 
Berdasarkan tabel 1 Rerata umur responden pada penelitian ini adalah 55,97 tahun dan tergolong pada kategori lansia, semakin bertambah umur seseorang maka semakin tinggi penurunan fisiologis yang terjadi, hal tersebut disebabkan oleh proses penuaan (Depkes RI, 2016). Adanya proses penuaan menyebabkan penurunan fisiologis pada lansia dan beresiko mengalami penyakit tidak menular seperti hipertensi, stroke, artritis, Penyakit Paru Obstruktif Kronik (PPOK), dan diabetes mellitus. Sejalan dengan data Riskesdas, (2018) dimana pravelensi penyakit gagal ginjal kronik tertinggi yaitu pada rentang umur 45 sampai dengan > 75 tahun dengan pravelensi yaitu $21,08 \%$. Pada usia $\geq 40$ tahun akan terjadi penurunan jumlah nefron fungsional pada ginjal akibat nefrosklerosis dan glomerulosklerosis, akibatnya pasien dengan usia tua akan mengalami gagal ginjal kronik dan memerlukan terapi hemodialisis (Subhan, 2018). Pada penelitian ini juga didapatkan sebanyak 16,7\% responden berusia $<45$ tahun, hal tersebut dipengaruhi oleh beberapa faktor, hipertensi merupakan salah satu penyebab tertinggi terjadinya penyakit gagal ginjal kronik pada usia $<45$ tahun di unit hemodialisis RS Ginjal Rasyida, Medan (Siagian dan Damayanty, 2018). Selain hipertensi, penyakit diabetes mellitus juga memiliki hubungan yang signifikan dengan kejadian gagal ginjal kronik pada usia muda
(J, 2016). Faktor gaya hidup yang tidak sehat menjadi penyebab utama terjadinya penyakit tidak menular seperti hipertensi dan diabetes mellitus pada usia muda. Gaya hidup yang tidak sehat yang sering diterapkan pada usia muda, seperti tingginya konsumsi makanan cepat saji yang tinggi garam, gula, dan lemak, rutinitas pekerjaan dan kesibukan yang menyebabkan stress, kurang tidur, kurangnya aktivitas fisik, tingginya konsumsi kopi, minuman berenergi, konsumsi suplemen dengan jangka panjang, serta kurangnya konsumsi air putih yang menjadi faktor resiko terjadinya kerusakan pada ginjal (Dharma, 2014). Gaya hidup yang tidak sehat tersebut cenderung dilakukan oleh laki-laki, dimana tingkat kesadaran kesehatan pada perempuan memiliki nilai rata-rata lebih tinggi daripada laki-laki, yang artinya perempuan cenderung lebih positif dalam menyikapi jenis makanan sehat daripada laki-laki (Sukma, 2012). Sehingga dalam penelitian ini, mayoritas responden yang berjenis kelamin laki-laki $(72,7 \%)$. Kondisi ini juga berkaitan dengan rendahnya kesadaran terhadap gaya hidup sehat, misalnya merokok, pola makan yang buruk, dan konsumsi alkohol. Sebagian besar laki-laki cenderung pola makan yang tidak teratur, memiliki kebiasaan merokok, dan mengkonsumsi minuman beralkohol, hal tersebut memeliki pengaruh terhadap terjadinya gagal ginjal kronik (Fahmia, et al., 2012). 
Tabel 1. Karakteristik Responden

\begin{tabular}{ccccc}
\hline Karakteristik & $\begin{array}{c}\text { Jumlah } \\
(\mathbf{n})\end{array}$ & $\begin{array}{c}\text { Persen } \\
(\mathbf{\%})\end{array}$ & Min-Max & Rerata \pm SD \\
\hline Umur & 1 & 1.5 & & \\
$17-25$ tahun & 4 & 6.1 & & \\
$26-35$ tahun & 6 & 9.1 & $25-80$ & $55,97 \pm 12,38$ \\
$36-45$ tahun & 15 & 22.7 & & \\
$46-55$ tahun & 25 & 37.9 & & \\
$56-65$ tahun & 15 & 22.7 & \\
$>65$ tahun & & & & \\
Jenis Kelamin & 48 & 72.7 & \\
Laki-Laki & 18 & 27.3 & \\
Perempuan & & & & \\
Jenis Penyakit & 30 & 45.5 & \\
Melitus & & & \\
Gagal Ginjal Kronik Dengan Diabetes & 36 & 54.5 & \\
Gagal Ginjal Kronik Tanpa Diabetes & & & \\
Melitus & $\mathbf{6 6}$ & $\mathbf{1 0 0 . 0}$ &
\end{tabular}

IMT menjadi salah satu penilaian yang dapat dilakukan untuk mengetahui status gizi pasien hemodialisis, yaitu dengan menghitung berat badan kering dalam kilogram dibagi dengan tinggi badan dalam meter ${ }^{2}$. Pada penelitian ini didapatkan perbedaan IMT pasien hemodialisis dengan dan tanpa diabetes mellitus $(\mathrm{p} \leq 0,05)$. Pada tabel 2 didapatkan rata-rata IMT pasien hemodialisa dengan diabetes mellitus lebih rendah yaitu $16,8 \mathrm{~kg} / \mathrm{m}^{2}$. Hal yang sama ditemukan pada penelitian yang dilakukan oleh Subhan, (2018) yang menunjukan hasil rata-rata IMT lebih tinggi pada pasien gagal ginjal kronik tanpa diabetes mellitus dibandingkan pasien gagal ginjal kronik dengan diabetes mellitus yang menjalani hemodialisis rutin.

Pasien hemodialisa rentan mengalami masalah status gizi kurang, salah satunya dapat dilihat dari nilai IMT yaitu kurang dari $18,5 \mathrm{~kg} / \mathrm{m}^{2}$. Kondisi organ ginjal yang mengalami kerusakan sehingga proses eksresi zat-zat sisa metabolisme terganggu dan menyebabkan uremia yang menimbulkan rasa mual, muntah sehingga pasien mengalami penurunan nafsu makan terutama asupan energi dan protein (Ma 'shumah et al., 2014). Kondisi tersebut menyebabkan simpanan zat gizi terutama energi dan juga protein didalam tubuh tidak optimal, dan menyebabkan nilai IMT kurang dari $18,5 \mathrm{~kg} / \mathrm{m}^{2}$. Pada penelitian yang dilakukan oleh Padoli dan Ayunda Bella, (2017) banyak pasien gagal ginjal kronik yang menjalani hemodialisis mengalami gangguan gastrointestinal berupa mual dan muntah akibat adanya perubahan tekanan darah, UFR yang terlalu cepat, adanya cemas, dan rentan mengalami anoreksia sehingga beresiko mengalami malnutrisi.

Rendahnya IMT pasien hemodialisis dengan diabetes mellitus dibandingkan pasien hemodialisis tanpa diabetes mellitus disebabkan oleh banyak faktor, baik dari 
tindakan hemodialisa itu sendiri maupun akibat penyakit yang diderita. Salah satu yang masalah yang beresiko terjadi pada pasien hemodialisa adalah gangguan nafsu makan, yang disebabkan oleh adanya uremia dan juga kondisi dialysis associated sympotmps yang lebih beresiko terjadi pada pasien hemodialisa dengan diabetes mellitus, dimana penggunaan cairan dialisat bebas glukosa dapat meningkatkan resiko kehilangan glukosa sebesar 25-30 gr setiap sesi hemodialisa, kondisi ini menyebabkan mual dan muntah setelah pasien melakukan hemodialisa yang dapat mengganu nafsu makan pasien (Aisara, et al., 2018). Kondisi tersebut dapat lebih beresiko terjadi pada pasien hemodialisa dengan diabetes mellitus akibat adanya pembatasan diet karbohidrat. Pasien hemodialisis rentan mengalami penurunan nafsu makan sehingga beresiko mengalami penurunan asupan zat gizi terutama asupan energi dan protein. Hal ini juga yang turut akan mempengaruhi terjadinya anemia dan hipoalbuminemia pada pasien gagal ginjal kronik. Sesuai dengan penelitian yang dilakukan oleh Chadijah and Wirawanni, (2013), bahwa asupan protein pasien gagal ginjal kronik dengan diabetes mellitus lebih rendah dibandingkan dengan tanpa diabetes mellitus, dan kondisi tersebut menyebaban nilai $\mathrm{Hb}$ dan albumin yang lebih rendah pada pasien gagal ginjal kronik dengan diabetes mellitus.
Selain itu, adanya perbedaan metabolisme pasien hemodialisa dengan dan tanpa diabetes mellitus juga berpengaruh terhadap perbedaan nilai IMT, dimana metabolisme pasien hemodialisa dengan diabetes mellitus diasumsikan karena adanya resistensi insulin menyebabkan terganggunya proses glikogenesis yaitu proses pembentukan glukosa menjadi glikogen yang kemudian disimpan di otot dan jaringan. Sehingga glikogen yang disimpan didalam tubuh tidak optimal. Untuk mendapatkan energi, tubuh akan memecah glikogen menjadi glukosa melalui proses glikogenolisis, kondisi diabetes mellitus menyebabkan terhambatnya pembentukan glikogen, sehingga tubuh akan memecah cadangan makanan lain untuk tetap dapat menghasilkan energi melalui proses glukoneogenesis, dengan mengubah cadangan makanan lain selain glikogen yang berasal dari karbohidrat dengan menggunakan lemak (gliserol) dan asam amino (protein) menjadi glukosa untuk kemudian dapat menghasilkan energi, dimana sebagian besar asam lemak dan asam amino disimpan di jaringan adiposa dan otot. Sehingga proses glikogenolisis dan glukoneogenesis yang terjadi terus menerus akan menyebabkan massa otot dan jaringan berkurang yang dilihat dari terjadinya penurunan berat badan atau status gizi pada pasien gagal ginjal kronik dengan diabetes mellitus (Subhan, 2018). Sehingga, pasein hemodialisis dengan diabetes mellitus memiliki IMT yang lebih rendah. 
Penilaian status gizi pasien hemodialisis perlu dilakukan untuk memonitoring status gizi pasien secara rutin. Karena pada pasien hemodialisis baik dengan maupun tanpa diabetes mellitus beresiko mengalami status gizi kurang, baik dari faktor fisiologis dan adanya inflamasi maupun dari asupan makan pasien terutama asupan energi dan protein. Asupan yang kurang pada pasien hemodialisis sebagian besar dipengaruhi oleh masalah gastrointestinal yang menyebabkan penurunan nafsu makan. Kondisi status gizi kurang pada pasien hemodialisis menjadi salah satu penyebab meningkatnya angka morbiditas dan mortalitas pasien hemodialisis. Menurut Afshar, et al (2011); (Mahdalena, 2017) menyatakan bahwa status gizi yang kurang pada pasien hemodialisis dapat menyebabkan penderita mengalami gejala seperti lelah, malaise, sakit kepala, kehilangan berat badan, kelemahan otot, infeksi berulang, penyembuhan luka yang lambat, serta gangguan tulang, sehingga dapat menyebabkan terjadinya penurunan kualitas hidup pasien hemodialisis. Oleh karena itu, untuk mengatasi dan mencegah terjadinya malnutrisi pada pasien hemodialisis perlu dilakukan monitoring dan evaluasi secara berkala dan melihat berbagai faktor yang dapat menyebabkan malnutrisi pada pasien hemodialisis. Manajamen atau tatalaksana malnutrisi pasien hemodialisis menurut Salwani, (2016) meliputi identifikasi dan talaksana penyebab malnutrisi, dukungan nutrisi/terapi diet yang adekuat, optimalisasi dialisis $(\mathrm{Kt} / \mathrm{V}>1,2$ pada pasien $\mathrm{HD} 3$ kali/minggu dan $\mathrm{Kt} / \mathrm{V}>1,8$ pada pasien $\mathrm{HD} 2$ kali/minggu) disertai monitoring adekuasi dialisis secara rutin, mengatasi kondisi medis yang memperberat malnutrisi seperti asidosis metabolik, infeksi, anemia, depresi serta gangguan gastrointestinal, konseling gizi, evaluasi obat-obatan yang menyebabkan nafsu makan menurun, suplementasi oral serta obat yang dapat meningkatkan nafsu makan.

Sebagian besar pasien hemodialisis baik dengan dengan diabetes mellitus maupun tanpa diabetes mellitus tergolong anemia berdasarkan kriteria WHO, (2014) dengan rata-rata kadar hemoglobin $<11,7$ gr/dl. Pada tabel 2 pasien hemodialisis tanpa diabetes mellitus memiliki nilai rata-rata yang lebih tinggi yaitu 10,3 gr/dl dibandingkan dengan pasien hemodialisis dengan diabetes mellitus $(\mathrm{p} \leq 0,05)$.

\section{Defisiensi hormone eritropoietin} (EPO) akibat adanya kerusakan ginjal merupakan salah satu faktor utama yang menyebabkan terjadinya anemia pada pasien gagal ginjal kronik. Dimana EPO seharusnya disekresikan oleh sel peritubuler ginjal yang berfungsi untuk merangsang sumsum tulang belakang untuk membentuk sel darah merah pada saat tubuh mengalami kekurangan sel darah merah yang ditandai dengan terjadinya hipoksia yaitu pada saat sel dan jaringan tubuh kekurangan oksigen. Namun, akibat adanya kerusakan dan penurunan fungsi ginjal 
EPO tidak dapat disekreskan secara optimal. Defesiensi EPO pada pasien gagal ginjal kronik menyebabkan proses pembentukan sel darah merah terganggu dan terjadinya penurunan konsentrasi $\mathrm{Hb}$. Faktor lain yang juga dapat menyebabkan terjadinya anemia pada pasien gagal ginjal kronik yang menjalani hemodialisis adalah defisiensi besi dari asupan makanan, darah yang tertinggal didialiser, serta kehilangan darah akibat pengambilan darah untuk kontrol biokimia (Sekarwana, 2004 dalam (Afshar et al., 2010). Faktor-faktor tersebut sangat beresiko menyebabkan terjadinya penurunan hemoglobin sehingga menyebabkan anemia pada pasien gagal ginjak kronik. Sejalan dengan penelitian yang dilakukan oleh Adiatma and Tobing, (2014) bahwa sebagian besar 30 subjek peneltian (86\%) memiliki anemia berdasarkan kriteria WHO.

Adanya perbedaan nilai $\mathrm{Hb}$ dalam penlitian ini diasumsikan pada pasien hemodialisis dengan diabetes mellitus sudah mengalami kerusakan pada tubulointerstisial atau bagian interstisial ginjal yang berkaitan dan disebabkan oleh kondisi resistensi insulin dan hiperglikemia yang sudah mulai terjadi pada awal penyakit diabetes mellitus, bahkan sebelum terjadi penurunan LFG maupun albuminuria (Anita, 2015). Kondisi tersebutlah yang menyebabkan penurunan produksi hormone eritropoietein, yaitu hormone yang dihasilkan oleh ginjal yang berfungsi untuk membentuk sel darah merah, lebih dulu terjadi pada pasien hemodialisis dengan diabetes mellitus, sehingga anemia dapat lebih beresiko pada pasien gagal ginjal kronik disertai diabetes mellitus. Berbeda pada pasien hemodialisa tanpa diabetes mellitus yang mengalami penurunan fungsi ginjal mulai terjadi pada saat LFG ginjal mengalami penurunan dan terjadi gagal ginjal kronik.

$\begin{array}{rrr}\text { Resistensi } & \text { insulin mengakibatkan } \\ \text { glukosa dalam darah tidak dapat }\end{array}$
dimetabolisme secara normal oleh tubuh melalui proses glikogenesis yaitu proses pembentukan glukosa menjadi sehingga kadar glukosa darah terus meningkat atau hiperglikemia. Kondisi hiperglikemia yang terus menerus dan tidak terkontrol dapat mengakibatkan berbagai komplikasi, salah satunya ialah terjadi kerusakan mikrovaskular atau pembuluh kecil pada tubuh yaitu pada ginjal, sehingga menyebabkan penurunan sekresi hormone eritropoeitin oleh ginjal untuk menstimulasi proses ertiropoesis yaitu proses pembentukan sel darah merah di sumsum tulang belakang terganggu. Komplikasi mikrovaskular pada pasien diabetes mellitus menyebabkan perubahan pada pembuluhu darah kecil atau mikrovaskular ginjal yaitu penyumbatan dan perubahan struktur, sehingga ginjal tidak mampu mensekresi EPO secara optimal (Yuhelma, et al., 2015). Selain itu, defisiensi besi yang disebabkan oleh penurunan asupan makanan terutama asupan protein pada pasien 
hemodialisa dengan diabetes mellitus juga turut mempengaruhi nilai $\mathrm{Hb}$.

Sebagaimana diketahui bahwa diabetes mellitus merupakan salah satu penyebab tertinggi terjadinya gagal ginjal kronik. Menurut CDC, (2014) penyakit diabetes mellitus menempati urutan pertama sebagai penyebab terbanyak terjadinya gagal ginjal kronik atau penyakit ginjal kronik (PGK) dengan insiden sebesar $44 \%$. Selain itu, konsumsi jenis obat tertentu pada penderita diabetes mellitus seperti metformin, fibrat, thiazolidinediones, dan angiotensinconverting enzyme inhibitor (ACE Inhibitor) merupakan faktor lain yang dapat mempengaruhi kadar $\mathrm{Hb}$ (Anita, 2015). Menurut (Mohanram, Zhang dan Shahinfar, 2008; Lia Dwi Pratiwi, 2018) ACE inhibitor dan angiotensin receptor blockers dapat menyebabkan penurunan reversible konsentrasi $\mathrm{Hb}$ pada pasien gagal ginjal kronik, mekanismenya yaitu dengan memblokade langsung efek proerytropoetic dari angiotensin II pada prekursor sel darah merah. Sehingga konsumsi obat jenis tersebut dapat beresiko tinggi menyebabkan anemia pada pasien hemodialisis dengan dan tanpa diabetes mellitus.

Sebagian besar pasien hemodialisis baik dengan diabetes mellitus maupun tanpa diabetes mellitus memiliki nilai albumin yang rendah. Namun dari kedua kelompok nilai median kadar albumin pada pasien hemodialisis dengan diabetes mellitus lebih rendah, dapat dilihat pada tabel 2 dengan nilai median kadar albumin pasien hemodialisis dengan diabetes mellitus yaitu 3,1 gr/dl. Terdapat perbedaan yang signifikan antara kadar albumin pasien hemodialisis dengan dan tanpa diabetes mellitus $(\mathrm{p} \leq 0,05)$. Hasil ini mendukung penelitian yang dilakukan oleh Rochmaningsih, (2018) yang menunjukan hasil ada perbedaan kadar albumin serum pasien gagal ginjal kronik dengan diabetes mellitus dan gagal ginjal kronik non diabetes mellitus, dimana pasien gagal ginjal kronik dengan diabetes mellitus memiliki rata-rata yang lebih rendah dibandingkan dengan pasien gagal ginjal kronik non diabetes mellitus. 
Tabel 2. Distribusi Frekuensi Indeks Massa Tubuh (IMT), Kadar Hemoglobin, Albumin, Ureum Dan Kreatinin Berdasarkan Jenis Penyakit Penyerta

\begin{tabular}{cllll}
\hline Kelompok & \multicolumn{1}{c}{ Variabel } & \multicolumn{1}{c}{ Mean \pm SD } & Median \pm SE & Min-Max \\
\hline GGK Dengan DM & IMT & $16,8 \pm 1,39$ & - & $14,0-19,1$ \\
& Kadar Hb & $9,1 \pm 1,42$ & - & $6,5-11,5$ \\
& Kadar Albumin & - & $3,1 \pm 0,03$ & $2,5-3,4$ \\
& Kadar Ureum & - & $117,5 \pm 3,06$ & $54,5-128,0$ \\
& Kadar Kreatinin & $8,7 \pm 3,46$ & - & $2,8-16,0$ \\
\hline GGK Tanpa DM & IMT & $18.1 \pm 1,28$ & - & $16,2-21,3$ \\
& Kadar Hb & $10,3 \pm 0,87$ & - & $8,5-11,6$ \\
& Kadar Albumin & - & $3,3 \pm 0,03$ & $2,9-4,1$ \\
& Kadar Ureum & - & $121,7 \pm 0,92$ & $99,8-132,5$ \\
& Kadar Kreatinin & $10,5 \pm 2,78$ & - & $5,2-17,5$ \\
\hline
\end{tabular}

Kadar albumin menjadi salah satu indikator biokimia yang dapat digunakan untuk melihat status gizi, rendahnya kadar albumin darah dapat menghambat fungsi pengantaran zat gizi ke dalam jaringan dan dapat menimbukan terjadinya edema. Albumin berfungsi mempertahankan tekanan osmotik agar cairan tidak berpindah dari dalam pembuluh darah ke jaringan (Kee, 2014). Nilai albumin yang rendah dapat meningkatkan resiko terjadinya mortalitas pasien. Kondisi ini dipengaruhi karean adanya kerusakan glomerulus pada ginjal dan juga faktor asupan makanan yang cenderung mengalami penurunan akbiat dari kondisi mual dan muntah yang sering dialami oleh pasien hemodialisa.

Rendahnya kadar albumin pada pasien hemodialisis dengan diabetes mellitus dipengaruhi oleh berbagai faktor. Faktor yang paling utama dan mendasar adalah adanya hiperglikemia yang kronis pada pasien diabetes mellitus menyebabkan terjadinya komplikasi mikrovaskuler yaitu pada glomerulus ginjal, sehingga mengakibatkan penurunan fungsi ginjal. Akibatnya, albumin ikut terbawa bersama dengan urin atau yang disebut sebagai kondisi albuminuria (Anita, 2015). Kondisi ini, sudah lebih dulu terjadi yang disebabkan adanya kerusakan mikrovaskular akibat hiperglikemia pada pasien diabetes mellitus sebelum pasien mengalami penurunan LFG yang kronis dan harus menjalani hemodialisa. Menurut Latifah, I; Suswardani, DL; Kusumawati, (2012) rendahnya kadar albumin pada pasien hemodialisis juga dipengaruhi oleh adanya inflamasi dan penyakit penyerta, salah satunya adalah penyakit diabetes mellitus yang cenderung akan mengalami albuminuria yang disebabkan proses degradasi dan ekskresi albumin sehingga pasien hemodialisis dengan diabetes mellitus beresiko lebih besar memiliki nilai albumin tidak normal. Selain faktor tersebut, resiko mual muntah pada pasien hemodialisis menyebabkan asupan makan yang kurang, terutama sumber protein yang merupakan sumber makanan dengan kandungan albumin tinggi. Albumin yang merupakan bentuk 
cadangan protein di dalam darah, sangat dapat

meningkatkan

terjadinya beresiko ikut terbuang ke cairan dialisat pada hipoalbuminemia pada pasien hemodialisis. saat proses hemodialisis, hal tersebut juga

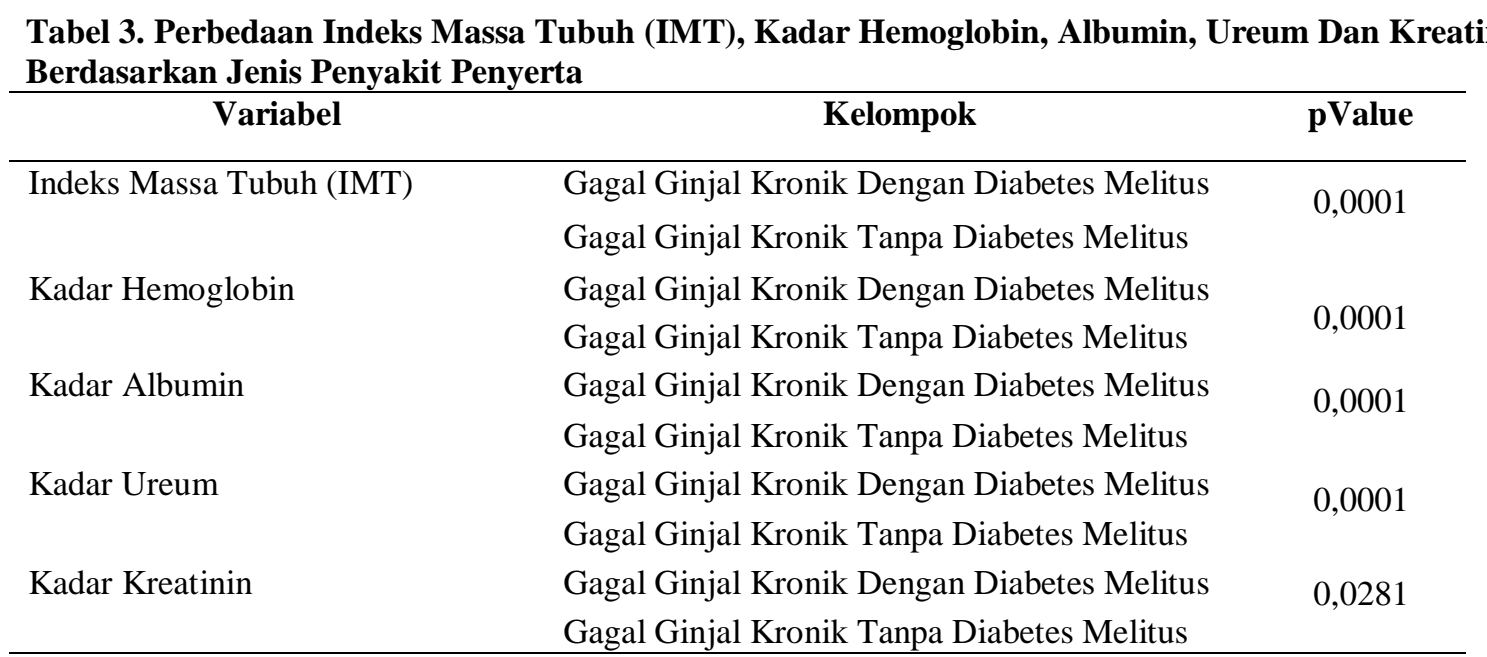

Kadar ureum menjadi salah satu indicator terjadinya penurunan LFG dan fungsi ginjal, dimana ureum yang merupakan sisa hasil metabolisme penguraian protein dan senyawa kimia lain yang mengandung nitrogen akan dialirkan oleh pembuluh darah menuju glomerulus ginjal, yang kemudian akan dikeluarkan melalui urin. Jika ginjal mengalami penurunan fungsinya, maka ureum dalah darah tidak dapat dikeluarkan dan dapat menyebabkan terjadinya uremia. Dari hasil penelitian yang ditunjukan pada table 3 menunjukan hasil bahwa terdapat perbedaan yang signifikan antara kadar ureum pasien hemodialisis dengan dan tanpa diabetes mellitus $\quad(p \leq 0,05)$. Seluruh responden memiliki nilai ureum diatas nilai normal yaitu 15-43 mg/dl, Hasil ini sejalan dengan penelitian yang dilakukan oleh Heriansyah et al., (2019), yang menunjukan hasil bahwa seluruh responden gagal ginjal kronik yang menjalani hemodialisis memiliki rata-rata kadar ureum yang tinggi, yaitu 122,5 mg/dl.

Tingginya kadar ureum pada pasien hemodialisis, selain disebabkan karena terjadinya penurunan fungsi ginjal yang progresif dan bersifat irreversible, juga dapat disebabkan dari asupan protein, terutama protein dengan nilai biologis yang rendah. Menurut Suryawan et al., (2016) salah satu pemicu peningkatan kadar ureum darah pada penderita gagal ginjal kronik adalah sumber protein tinggi dalam makanan seperti telur, susu, daging, semua jenis kacang-kacangan termasuk olahannya seperti tempe dan tahu. Penelitian yang dilakukan oleh (Nugroho et $a l$. , 2018) diperoleh hasil bahwa rata-rata asupan protein pada pasien hemodialisis sebelum dilakukan konseling gizi, lebih banyak mengkonsumsi jenis protein nabati 
secara rutin seperti tempe dan tahu dan tidak memperhatikan makanan yang boleh dikonsumsi sesuai diet, sehingga menyebabkan nilai rata-rata kadar ureum yang tinggi yaitu 166,1 mg/dl, yang kemudian setelah diberikan konseling gizi pasien mengubah jenis asupan protein yang bervariasi dan mengutamakan sumber protein hewani seperti ikan, telur, daging, ayam ratarata kadar ureum pasien mengalami penurunan yaitu dari kisaran 97-321 mg/dl menjadi $87-171 \mathrm{mg} / \mathrm{dl}$. Jenis protein nabati memiliki nilai biologis yang rendah dibandingkan dengan jenis protein hewani, jenis protein yang memiliki nilai biologis rendah dapat menghasilkan lebih banyak sisa metabolisme yang tidak dapat digunakan kembali oleh tubuh, dimana salah satu sisa metobolisme asam amino adalah ureum. Sehingga, asupan protein yang dianjurkan bagi penderita gagal ginjal kronik adalah protein dengan nilai biologis tinggi.

Pada tabel 2 didapatkan nilai median kadar ureum pasien hemodialisis tanpa diabetes mellitus lebih tinggi yaitu 121,7 $\mathrm{mg} / \mathrm{dl}$. Penelitian ini sejalan dengan penelitian yang dilakukan oleh Chadijah \& Wirawanni, (2013) yaitu terdapat perbedaan kadar ureum pada pasien gagal ginjal kronik, dengan nilai median kadar ureum pasien gagal ginjal kronik tanpa diabetes mellitus lebih tinggi dibandingkan dengan pasien dengan diabetes mellitus. Tingginya kadar ureum pada pasien hemodialisis tanpa diabetes mellitus, diasumsikan selain adanya penurunan fungsi ginjal yang bersifat progresif, juga diakibatkan karena kondisi pasien hemodialisis tanpa diabetes mellitus memiliki inflamasi yang lebih rendah dibandingkan dengan pasien hemodialisis dengan diabetes mellitus, dimana pasien hemodialisis dengan diabetes mellitus dengan kondisi hiperglikemia yang akut, salah satunya dapat menyebabkan ketoasidosis diabetic akibat dari proses metabolisme pembentukan glukosa dari lemak, akibat resistensi insulin sehingga tubuh tidak dapat menyimpan glukosa menjadi glikogen, akibat dari proses tersebut menghasilkan sisa metabolisme berupa keton. Kondisi tersebut salah satunya dapat menyebabkan gangguan gastrointestinal seperti mual dan muntah, sehingga dapat menyebabkan penurunan nafsu makan pada pasien hemodialisis dengan diabetes mellitus dan memiliki asupan protein yang lebih rendah. Selain itu, adanya pembatasan mengonsumsi bahan makanan karena penyakit komplikasi yang diderita, seperti pembatasan kalium, natrium, glukosa dan pembatasan asupan cairan mengakibatkan asupan energi maupun protein menjadi defisit (Farhat, Fathurrahman and Abdurrachim, 2016).

Ureum merupakan senyawa amonia yang bersumber dari metabolisme asam amino yang diubah oleh hati, kadar ureum serum mencerminkan keseimbangan anatara produksi dan ekskresi yaitu dengan mengukur 
nilai Blood Urea Nitrogen (BUN), nilai BUN akan meningkat apabila seseorang mengonsumsi protein dengan jumlah berlebih (Nugroho et al., 2018). Menurut (Aisara, et $a l .$, (2018) penggunaan cairan dialisat bebas glukosa pada pasien hemodialisa menyebabkan kehilangan glukosa sebanyak 25-30 gr per sesi hemodialisa dan menyebabkan kondisi dialysis associated symptoms, dan salah satu efeknya mirip dengan gejala hipoglikemia yaitu sakit kepala, mual, dan muntah. Kondisi tersebut dapat lebih beresiko terjadi pada pasien hemodialisa dengan diabetes mellitus, dimana adanya pembatasan diet glukosa dari asupan karbohidrat menyebabkan kondisi dialysis associated symptoms lebih besar terjadi dan menyebabkan salah satunya adalah penurunan asupan makan, terutama asupan protein sehingga berpengaruh terhadap zat sisa dari metabolisme protein yaitu ureum dan kreatinin yang lebih rendah, serta kondisi anemia dan hipoalbumin yang lebih tinggi pada pasien hemodialisa dengan diabetes mellitus.

Kreatinin merupakan zat sisa metabolisme protein yang berasal dari simpanan protein di otot, banyak dijumpai diotot rangka dan dihasilkan dari keratin pada metabolisme otot saat menghasilkan energi. Menurut Suryawan et al., (2016) dalam proses pembentukan energi yaitu dengan mensintesis ATP dari ADP pada metabolisme otot, kreatinin fosfat yang merupakan sumber energi yang akan diubah menjadi energi, akan menghasilkan sisa metabolisme berupa kreatinin yang dikatalisasi oleh enzim kreatinin kinase akan dibawa ke ginjal untuk kemudian di keluarkan melalui urin.

Terjadinya penurunan fungsi ginjal yang bersifat irreversible pada pasien gagal ginjal kronik, menyebabkan kadar kreatinin darah meningkat. Hemodialisa dilakukan akibat dari terjadinya penurunan fungsi ginjal yang parah, baik akut maupun kronis, merupakan ancaman bagi kehidupan dan memerlukan penghilangan produk limbah beracun dan pemulihan volume dan komposisi cairan tubuh terhadap keadaan normal dengan mengambil zat-zat nitrogen yang bersifat toksik dari dalam tubuh pasien ke dializer tempat darah tersebut dibersihkan dan kemudian dikembalikan ketubuh pasien (Hutagaol, 2017). Selain itu, faktor lain yang dapat meningkatkan kadar kreatinin darah adalah tingginya asupan protein. Menurut Markum, (2006); (Chadijah and Wirawanni, 2013) yang mempengaruhi meningkatnya plasma kreatinin dalam darah antara lain diit tinggi protein serta yang mempengaruhi menurunnya plasma kreatinin dalam darah adalah diit rendah protein dan berkurangnya massa otot karena kurus. Berdasarkan tabel 2, responden pada penelitian ini seluruhnya memiliki kadar kreatinin darah yang tinggi. Peningkatan kadar ureum selalu dibarengi dengan peningkatan kadar kreatinin, hal ini disebabkan karena terjadinya penurunan 
fungsi ginjal yang progresif dan bersifat irreversible sehingga semakin terjadi peurunan glomerulus (Suryawan, et al., 2016). Hasil ini sejalan dengan penelitian yang dilakukan oleh Heriansyah et al., (2019) bahwa seluruh responden memiliki kadar kreatinin serum yang tinggi dengan rata-rata kadar kreatinin serum 9,9 mg/dl.

Pada table 2 didapatkan nilai rata-rata kadar kreatinin lebih tinggi pada pasien hemodialisis tanpa diabetes mellitus yaitu $10,5 \mathrm{mg} / \mathrm{dl}$. Hasil ini menunjukan perbedaan yang signifikan antara kadar kreatinin pasien dengan dan tanpa diabetes mellitus $(\leq 0,05)$. Hasil ini mendukung hasil penelitian yang dilakukan oleh Chadijah \& Wirawanni, (2013) menyebutkan bahwa pasien gagal ginjal kronik tanpa diabetes mellitus memiliki kadar kreatinin yang lebih tinggi dibandingkan dengan pasien gagal ginjal kronik dengan diabetes mellitus, yang diasumsikan memiliki asupan protein yang lebih tinggi.

Rendahnya kadar kreatinin dalam darah dipengaruhi oleh diet rendah protein dan berkurangnya massa otot karena kurus (Chadijah \& Wirawanni, 2013). Pada penelitian ini penurunan massa otot yang terjadi pada pasien hemodialisis dengan diabetes mellitus, yang ditandai dengan nilai IMT lebih rendah juga mempengaruhi kadar kreatinin dalam darah. Massa otot yang lebih tinggi pada pasien hemodialisis tanpa diabetes mellitus kemungkinan besar akan mengakibatkan perombakan massa otot yang lebih banyak, sehingga menghasilkan sisa metabolisme berupa kreatinin yang lebih tinggi. Namun, tidak selamanya massa otot dapat mempengaruhi atau berhubungan dengan nilai IMT sesorang. Karena adanya kondisi pandemi saat ini yang tidak memungkinkan penliti untuk melakukan pengambilan data langsung dengan melakukan pengukuran massa otot responden. Sehingga salah satu indikator yang dapat digunakan adalah dengan melihat hubungan massa otot dan juga nilai IMT responden. Selain itu, tingginya kadar kreatinin serum juga dapat dipengaruhi oleh kondisi dehidrasi pada pasien hemodialisis dimana pada saat proses hemodialisis pasien akan mengalami banyak kehilangan penumpukan cairan, sehingga tidak jarang pasien akan mengalami dehidrasi yang menyebabkan kreatinin dalam darah menjadi pekat sehingga kadar kreatinin dalam darah menjadi tinggi (Suryawan, et al., 2016).

\section{KESIMPULAN}

Berdasarkan hasil penelitian, didapatkan bahwa ada perbedaan yang signifikan antara Indeks Massa Tubuh (IMT), kadar hemoglobin, kadar albumin, kadar ureum, dan kadar kreatinin pada pasien hemodialisis dengan dan tanpa diabetes mellitus. 


\section{UCAPAN TERIMAKASIH}

Terimakasih kepada RS Islam Jakarta Cempaka Putih, Ibu Sunarti, S. Gz,. MKM,. RD, Ibu Yani, dan Ibu Lastri, yang sudah membantu terlaksananya penelitian ini. Manuskrip ini telah diikutsertakan pada

\section{DAFTAR PUSTAKA}

Adiatma, D. and Tobing, M. (2014) Prevalensi Dan Jenis Anemia Pada Pasien Penyakit Ginjal Kronik Yang Menjalani Hemodialisis Reguler(Studi Di Rsup Dr. Kariadi Semarang), Jurnal Kedokteran Diponegoro.

Afshar, R. et al. (2010) 'Hematological profile of chronic kidney disease (CKD) patients in Iran, in pre-dialysis stages and after initiation of hemodialysis.', Saudi journal of kidney diseases and transplantation: an official publication of the Saudi Center for Organ

Transplantation, Saudi Arabia, 21(2), pp. 368-371.

Aisara, S., Azmi, S. and Yanni, M. (2018) 'Gambaran Klinis Penderita Penyakit Ginjal Kronik yang Menjalani Hemodialisis di RSUP Dr. M. Djamil Padang', Jurnal Kesehatan Andalas, 7(1), p. 42. doi: 10.25077/jka.v7i1.778.

Angraini, D. I. (2015) 'The Different Of Protein Intake Between Chronic Renal Failure Patients With Malnutrition And Not Malnutrition In Hemodialysis Unit At Dr. Abdul Moeloek Hospital Bandar Lampung', Jurnal Kedokteran Kesehatan: Publikasi Ilmiah Fakultas Kedokteran Universitas Sriwijaya, 2(2), pp. 163-168. Available at: https://ejournal.unsri.ac.id/ind
Scientific Article Writing Training (SAWT)

Batch V, Program Kerja GREAT 4.1e, Program Studi S1 Gizi, FIKES Universitas Esa Unggul dengan dukungan fasilitator: Dudung Angkasa, S.Gz., M.Gizi, RD; Khairizka Citra Palupi, S.Gz., M.S.

ex.php/j kk/article/view/2546.

Anita, D. C. (2015) 'Kadar Albumin Dan Hemoglobin Pasien Gagal Ginjal Kronis Dengan Diabetes Dan Non- Diabetes', Jurnal INJEC, 2(Dm), pp. $253-$ 262.

Anita, D. C. (2015) 'Kadar Albumin Dan Hemoglobin Pasien Gagal Ginjal Kronis Dengan Diabetes Dan Non- Diabetes', Jurnal INJEC, 2(Dm), pp. $253-$ 262.

Astrini, W. G. A. (2013) Hubungan Kadar Hemoglobin $(\mathrm{Hb}), \quad$ Indeks Massa Tubuh (IMT) Dan Tekanan Darah Dengan Kualitas Hidup Pasien Gagal Ginjal Kronik Yang Menjalani Hemodialisis Di RSUD Dokter Soedarso Pontianak Bulan April 2013.

CDC (2014) National Chronic Kidney Disease Fact Sheet: General Information and National

Estimates on Chronic Kidney Disease in the United States.

Atlanta: US Department of Health and Human Services.

Centers for Disease Control and Prevention. Available at: http://www.cdc.gov/diabetes/p ubs/fact sheets/kidney.htm.

Chadijah, S. and Wirawanni, Y. (2013) 'Perbedaan Status Gizi, Ureum Dan Kreatinin Pada Pasien Gagal Ginjal Kronik Dengan Diabetes Melitus Dan Non Diabetes Melitus Di RSUD Dr. Zainoel Abidin Banda Aceh', 
J.Gipas, November 2021, Volume 5 Nomor 2

ISSN 2599-0152 eISSN 2599-2465

http://jos.unsoed.ac.id/index.php/jgps

Journal of Nutrition and

Health, 1(1). doi: https://doi.org/10.14710/jnh.1.

1.2013. $\% 25 p$.

Damayanti, A. Y. (2017) 'Hubungan Asupan Protein Dan Kadar Kreatinin Penderita Gagal Ginjal Kronik Dengan Hemodialisis', Darussalam Nutrition Journal, 1(1), p. $33 . \quad$ doi: 10.21111/dnj.v1i1.1019.

Depkes RI (2016) 'Situasi Lanjut Usia (Lansia) di Indonesia',

Kementrian Kesehatan Republik Indonesia, pp. 1- 12.

Dharma, P. (2014) Penyakit Ginjal Deteksi Dini dan Pencegahan. Yogyakarta. CV Solusi Distribusi.

Fahmia, N. I., Mulyati, T. and Handarsari, E. (2012) 'Hubungan Asupan Energidan Protein dengan Status Gizi pada Penderita Gagal Ginjal Kronik yang Menjalani Hemodialisa Rawat Jalan di RSUD Tugurejo Semarang', Jurnal Gizi Universitas Muhammadiyah Semarang, 1(November), pp. 1-11.

Farhat, Y., Fathurrahman and Abdurrachim, R. (2016) 'Peranan Asupan Energi, Protein, Dan Lama Hemodialisa Terhadap Status Gizi Pada Pasien Gagal Ginjal Kronik Dengan Hemodialisa (Di RSUD Ratu Zalecha Martapura Tahun 2015)', Jurnal Skala Kesehatan, 7(2), pp. 1-12.

Hartini, E., Manurung, I. and Purwati (2014) 'Pengaruh hemodialisis terhadap diabetes melitus', Jurnal Keperawatan, $X(1), p p$. 1-6.

Heriansyah, Humaedi, A. and Widada (2019) 'Gambaran Ureum Dan Kreatinin Pada Pasien Gagal Ginjal Kronis Di RSUD

Karawang', Jurnal Binawan, 1(April), pp. 8-14.

Hutagaol, E. V. (2017) 'Peningkatan Kualitas Hidup Pada Penderita Gagal
Ginjal Kronik Yang Menjalani

Terapi Hemodialisis Melalui Pyschological Intervention Di Unit Hemodialisa RS Royal

Prima Medan Tahun 2016', Jurnal JUMANTIK, 2(1), pp. 42-59. doi:

10.1080/13507486.2015.1047603.

Indonesia Renal Registry (IRR) (2018) 11 th Report Of Indonesian Renal Registry 2018.

J, A. U. L. (2016) Faktor Resiko Kejadian Gagal Ginjal Kronik Pada Usia Dewasa Muda Di RSUD Dr. Moewardi.

Kee (2014) Pedoman Pemeriksaan Laboratorium \& Diagnostik. Jakarta: $\quad$ EGC Penerbit Buku Kedokteran.

Latifah, I; Suswardani, DL; Kusumawati, Y. (2012) 'Hubungan Antara Kadar Hemoglobin, Kadar Albumin, Kadar Kreatinin dan Status Pembayaran dengan

Kematian Pasien Gagal Ginjal Kronik di RSUD Dr. Moewardi', Jurnal Kesehatan, Volume 5(1), pp. 1- 15. Available at:

http://hdl.handle.net/11617/30

70.

Lia Dwi Pratiwi (2018) Perbedaan Kadar Hemoglobin Pada Penderita Gagal Ginjal Kronis Sebelum Dan Sesudah Hemodialisa (Studi di RSUD Jombang ).

Ma 'shumah, N. et al. (2014) 'Hubungan Asupan Protein Dengan Kadar Ureum, Kreatinin, Dan Kadar Hemoglobin Darah Pada Penderita Gagal Ginjal Kronik Hemodialisa Rawat Jalan Di RS Tugurejo, Semarang', Jurnal Gizi Universitas Muhammadiyah Semarang, 3(1), Pp. 22-32.

Mahdalena (2017) Status Nutrisi dan Cairan pada Pasien yang Menjalani Hemodialisa di RSUP $H$. Universitas Sumatera Utara. 
J.Gipas, November 2021, Volume 5 Nomor 2

ISSN 2599-0152 eISSN 2599-2465

http://jos.unsoed.ac.id/index.php/jgps

Markum, I. E. (2006) Pemeriksaan Penunjang Pada Penyakit Ginjal. Jakarta: FK-UI.

Nugroho, K. P. A. et al. (2018) 'Status Gizi, Kadar Hemoglobin, Ureum, Dan Kreatinin Pasien Konseling Gizi Hemodialisa', Jurnal Gizi Dan Dietetik Indonesia (Indonesian Journal of Nutrition And Dietetics), 5(1), P. $31 . \quad$ Doi: 10.21927/Ijnd.2017.5(1).31-43.

Padoli and Ayunda Bella, R. (2017) 'Kejadian Komplikasi

Intradialisis Klien Gagal Ginjal Kronik Di Ruang Instalasi Hemodialisis RSUD Dr. M Soewandhi Surabaya', Jurnal Keperawatan Indonesia, $X(1)$, pp. 26-32.

Riskesdas (2018) Hasil Utama Riset Kesehata Dasar (RISKESDAS) 2018, Journal of Physics A: Mathematical and Theoretical. doi: $\quad 10.1088 / 1751$ $8113 / 44 / 8 / 085201$.

Rochmaningsih, A. (2018) Perbedaan Kadar Albumin Serum Pada Pasien Gagal Ginjal Kronis Dengan Diabetes Mellitus Dan Non Diabetes Mellitus Di PKU Muhammadiyah Bantul.

Salwani, D. (2016) 'Malnurtisi pada gagal ginjal kronik', pp. 1-29.

Siagian, K. N. and Damayanty, A. E. (2018) 'Identifikasi Penyebab Penyakit Ginjal Kronik pada Usia Dibawah 45 Tahun di Unit Hemodialisis Rumah Sakit Ginjal Rasyida Medan Tahun 2015 Identifying Cause of Cronic Renal Disease Under 45 Years Old in Hemodialisis Unit at Rasyida Renal', Artikel

Penelitian Fakultas Kedokteran Universitas Muhammadiyah Sumatera Utara, 1(3), pp. 234237.

Subhan, T. A. (2018) Perbedaan Indeks Massa Tubuh (IMT) Pada Pasien Gagal Ginjal Kronik
Dengan DM Dan Tanpa $\quad$ DM

Yang Menjalani Hemodialisis Rutin Di RSUD Dr. Moewardi, Journal of Chemical Information and Modeling. doi: 10.1017/CBO9781107415324.

004.

Sukma, A. P. (2012) Kesadaran Kesehatan Dan Gaya Hidup Sehat Dengan Sikap Konsumen Pada Makanan Organik.

Suryawan, D. G. A., Arjani, I. A. M. S. and Sudarmanto, I. G. (2016) 'Gambaran Kadar Ureum Dan Kreatinin Serum Pada Pasien Gagal Ginjal Kronik yang Menjalanai Terapi Hemodialisa Di RSUD

Sanjiwani Gianyar', Meditory Journal, 4(1), pp. 145-153.

Verdiansah (2016) 'Pemeriksaan Fungsi Ginjal, Program Pendidikan Dokter Spesialis Patologi Klinik, Rumah Sakit Hasan Sadikin, Bandung, Indonesia', 43(2), pp. 148-154.

WHO (2014) Anaemia Policy Brief. Available at:http://www.who.int//iris/bits tream $/ 1$ 0665/148556/1/WHO_NMH_N HD_14.4_eng.pdf.

Yuhelma, Hasneli I, Y. and Annis N, F. (2015) Identifikasi dan Analisis Komplikasi Makrovaskuler dan Mikrovaskuler pada Pasien Diabetes Mellitus', Journal Online Mahasiswa, 2(1), pp. $\quad 569$ 579. 